\title{
Structural and Functional Effects of Herbicides on Non-Target Organisms in Aquatic Ecosystems with an Emphasis on Atrazine
}

\author{
J.F. Fairchild \\ U.S. Geological Survey, \\ USA
}

\section{Introduction}

Herbicide use has increased dramatically around the world over the past 6 decades (Gianessi and Reigner, 2007). Few herbicides were in use in the 1950s. However, by 2001 approximately 1.14 billion kilograms of herbicides were applied globally for the control of undesireable vegetation in agricultural, silvicultural, lawncare, aquacultural, and irrigation/recreational water management activities (Kiely et al., 2004). Twenty-eight percent of the total mass of herbicides is applied in the United States, with the remaining 72 percent being applied elsewhere around the globe (Kiely et al., 2004). Herbicides represent $36 \%$ of global pesticide use, followed by insecticides $(25 \%)$, fungicides $(10 \%)$ and other chemical classes (Kiely et al., 2004).

Agricultural production accounts for approximately $90 \%$ of herbicide use in the U.S. (Kiely et al., 2004). Gianessi and Reigner (2007) indicated that herbicides are routinely used on more than $90 \%$ of the area designated for large commercial crops including corn, soybeans, cotton, sugar beets, peanuts, and rice. Increased farm mechanization, technological advancements in production of inexpensive sources of inorganic nitrogen fertilizer (e.g., anhydrous ammonia), and conversion of forest, grassland, and wetland habitats to cropland has led to a tremendous increase in global food production over the past half-century. Herbicides have augmented advances in large-scale agricultural systems and have largely replaced mechanical and hand-weeding control mechanisms (Gianessi and Reigner, 2007).

The wide-spread use of herbicides in agriculture has resulted in frequent chemical detections in surface and groundwaters (Gilliom, 2007). The majority of herbicides used are highly water soluble and are therefore prone to runoff from terrestrial environments. In additon, spray drift and atmospheric deposition can contribute to herbicide contamination of aquatic environments. Lastly, selected herbicides are deliberately applied to aquatic environments for controlling nuisance aquatic vegetation. Although aquatic herbicide exposure has been widely documented, these exposures are not necessarily related to adverse non-target ecological effects on natural communities in aquatic environments. This chapter evaluates the potential for effects of herbicides on the structure and function of aquatic envrionments at the population, community, and ecosystem levels of biological 
organization. In this manuscript I examine several critical aspects of the subject matter area: primary herbicides in use and chemical modes of action; the regulatory process used for registration and risk assessment of herbicides; data regarding non-target risks and the relative sensitivity of aquatic plants, inveretebrates, and fish to herbicides; and emerging areas of science regarding the potential for endocrine-disrupting effects of herbicides on aquatic vertebrates. Much of the focus of this paper is on atrazine due to the extensive database which exists regarding its fate and effects.

\section{Herbicide production, use, and regulation in the United States}

\subsection{Herbicide production and use}

Agricultural statistics indicate that total herbicide use in the United States has been relatively stable to declining over the past 2 decades with an approximate average usage of 250 million kilograms per year (Fig. 1) (Kieley et al., 2004). Total herbicide use in the United States has remained relatively stable over the past 25 years due to the decrease in application rates of atrazine and the increased use of the low-volume chemicals such as the acetolactate synthase (ALS) inhibitors (Reade and Cobb, 2002; Menne and Kocher, 2007).

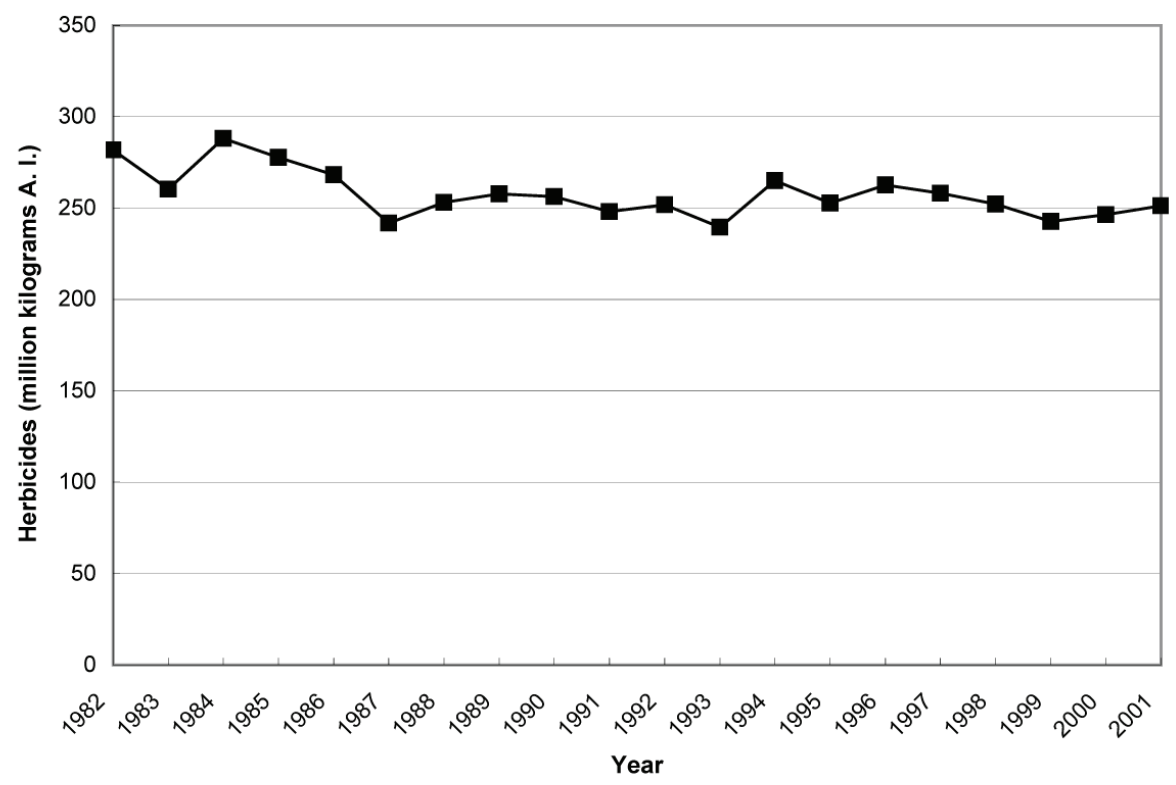

Fig. 1. Trendline in total herbicide use in the United States from years 1982 to 2001. Data from Kieley et al. (2004).

In 1987, the primary herbicides used in the United States were atrazine, alachlor, metolachlor, and 2,4-D (Table 1). The major change in herbicide use-trends has been driven by the significant increase in use of glyphosate due to the development of glyphosateresistant crops including soybeans, corn, and cotton. In 2001, glyphosate replaced atrazine in terms of total product application, followed by the increase in use of acetochlor and 2,4-D (Table 1). 


\begin{tabular}{|l|l|l|l|l|l|l|l|l|}
\hline \multirow{2}{*}{$\begin{array}{l}\text { Active } \\
\text { Ingredient }\end{array}$} & 2001 & \multicolumn{2}{l|}{1999} & \multicolumn{1}{l|}{1997} & \multicolumn{1}{l|}{1987} \\
\cline { 2 - 10 } & Rank & Range & Rank & Range & Rank & Range & Rank & Range \\
\hline Glyphosate & 1 & $39-41$ & 2 & $30-33$ & 3 & $15-17$ & 9 & $3-4$ \\
\hline Atrazine & 2 & $34-36$ & 1 & $34-46$ & 1 & $34-37$ & 1 & $32-34$ \\
\hline Acetochlor & 3 & $14-16$ & 3 & $14-16$ & 4 & $14-16$ & NA & NA \\
\hline 2,4-D & 4 & $13-15$ & 4 & $13-15$ & 5 & $13-15$ & 4 & $13-15$ \\
\hline Metolachlor-S & 5 & $9-11$ & 8 & $7-9$ & NA & NA & NA & NA \\
\hline Metolachlor & 6 & $12-14$ & 5 & $12-14$ & 2 & $27-31$ & 3 & $20-23$ \\
\hline Pendimethalin & 7 & $7-9$ & 6 & $8-10$ & 6 & $11-13$ & 7 & $3-5$ \\
\hline Trifluralin & 8 & $5-7$ & 7 & $8-10$ & 7 & $10-11$ & 5 & $11-14$ \\
\hline Alachlor & 9 & $3-3$ & 9 & $3-5$ & 8 & $6-7$ & 2 & $25-27$ \\
\hline Propanil & 10 & $3-4$ & 10 & $3-5$ & 9 & $3-4$ & 8 & $3-5$ \\
\hline Dimethenamid & 11 & $3-4$ & 12 & $3-4$ & 10 & $3-4$ & NA & NA \\
\hline EPTC & 12 & $2-4$ & 11 & $3-4$ & 11 & $3-4$ & 6 & $8-10$ \\
\hline Simazine & 13 & $2-3$ & NA 2 & NA & NA & NA & NA & NA \\
\hline Dicamba & 14 & $2-3$ & 13 & $3-4$ & 12 & $3-4$ & 10 & $2-3$ \\
\hline Sulfosate & 15 & $1-3$ & NA & NA & NA & NA & NA & NA \\
\hline
\end{tabular}

Data from Kiely et al. (2004).

Table 1. List of the major herbicides applied in the United States from 1987 to 2001 categorized by rank and amount of use (million kilograms/year).

There are approximately 220 registered herbicides that can be classified among 15 known herbicidal modes of action, whereas 48 herbicides have no identified modes of action (Cole et al., 2000; Read and Cobb, 2002; Menne and Kocher, 2007) (Table 2). The majority of

\begin{tabular}{|l|l|l|}
\hline Target site or Mode of Action & $\begin{array}{l}\text { Herbicide } \\
\text { \#'s }\end{array}$ & Examples of Chemical Classes \\
\hline Photosystem II & 59 & Triazines, Phenylureas \\
\hline Acetolactate synthase & 43 & Sulfonureas, Imidazolinone \\
\hline Microtubule and cell division & 29 & Chloroacetamides, Dinitroanalines \\
\hline Protoporphyrinogen oxidase & 28 & Diphenyl ethers, Triazolinones \\
\hline Auxin mimics & 20 & Phenoxy acids, Pyridines \\
\hline Acetyl CoA Carboxylase & 16 & Aryoxyphenoxypropionates \\
\hline Phytoene desaturase & 11 & Pyridazinone \\
\hline Hydroxyphenylpyruvate dioxygenase & 3 & Triketones, Isoaxazole \\
\hline Oxidative phosphorylation & 3 & Dinitrophenols \\
\hline Cellulose biosynthesis & 2 & Nitriles, Benzamides \\
\hline Photosystem 1 & 2 & Bypyridiliums \\
\hline Auxin transport & 1 & Phthalamate, Semicarbazones \\
\hline Dihydropteroate synthetase & 1 & Carbamates \\
\hline Glutamine synthetase & 1 & Phosphinic acids \\
\hline Lycopene cyclase & 1 & Dimethylamines \\
\hline Unknown or not stated & 48 & \\
\hline
\end{tabular}

Data from Cole et al. (2000), Read and Cobb (2002), and Menne and Kocher (2007).

Table 2. Target sites/mode of action of commercial herbicides ranged by number of products. 
herbicides, however, fall into a relatively small number of groups of modes of action including inhibitors of the photosystem II photosynthetic reaction; inhibitors of acetolactate synthase; inhibitors of cellular division; inhibitors of protoporhyrinogen IX oxidase; and the auxin mimics. These five modes of action are rather non-selective, which has led to proposed increases in research of herbicides using genomics to develop chemicals with new and unique modes of action that can be applied at low rates with high efficacy but that will not result in herbicidal resistance in weeds such as that recently observed with glyphosate and some acetolactate (ALS) inhibitors (Cole et al., 2000; Moss, 2002). It is anticipated that these newer modes of action would also have minimal effects on non-target aquatic organisms.

\subsection{Herbicide regulation}

Herbicides were first mass-produced in the early 1950s for the deliberate application to the environment for the control of weeds in agriculture, silviculture, right-of-ways, and turf lawns (Giannessi and Reigner, 2007). The history of herbicide registration and regulation has differed around the world depending on the structure of governments, the rate of scientific advancements, and the social perceptions of the need for environmental regulation. Over time we have seen major movements in developed countries toward harmonization of guidelines and requirements for herbicide registration and regulation.

United States: Herbicides and other pesticides have been regulated in the United States for over 60 years under a series of legislative mandates. Pesticide registrations were originally regulated under the Federal Insecticide, Fungicide, and Rodenticide Act (FIFRA) which was enacted in 1948 as an expansion of the Federal Water Pollution Control Act (FWPCA) of 1948. The U.S. Department of Agriculture (USDA) was responsible for regulation of pesticides in the U.S. until 1970 when responsibilities were transferred to the newly created U.S. Environmental Protection Agency (USEPA). Continued concern over the exposure and effects of pesticides on humans and non-target animals (invertebrates, fish, birds, mammals, and other wildlife) led to a total revision of the FIFRA in 1972. Substantial changes were made in 1988 to accelerate the pesticide re-registration process. The establishment of the Food Quality and Protection Act of 1996 (FQPA) brought further changes to the registration of pesticides including herbicides (Flynn, 2002; Saundry, 2006). Industrial chemicals were also first regulated under the FWPCA (1948) but requirements were subsequently revised under the Toxic Substances Control Act (TSCA) of 1976. Over the past decade testing guidelines for the effects of pesticides and industrial chemicals on non-target organisms have been harmonized and consolidated within the U.S. EPA Office of Chemical Safety and Pollution Prevention (OCSPP) (USEPA, 2010).

Europe: Prior to 1991, member states of the European Union (EU) used varying approaches in the registration and regulation of herbicides and other pesticides which collectively created a burden to agricultural trade and practices (Flynn, 2002). Therefore, the EU consolidated the regulation of herbicides and other plant protection products under Council Directive 91/414/EEC which was formally adopted on July 25, 1993 (Flynn 2002). Herbicides and other agricultural chemicals used in the European Union are now regulated under guidelines originally developed under the Organization for Economic Cooperation and Development (OECD) and more recently by the European Commission (EC; http://ecb.jrc.ec.europa.eu/). Further refinement of the pesticide registration process in Europe is expected to occur following the enactment of the Registration, Evaluation, 
Authorization and Restriction of Chemicals (REACH) legislation implemented in June 2007 (REACH, 2007) with a goal of total completion by the year 2015.

Canada: Herbicide regulation in Canada was first enacted under the Agricultural Pest Act of 1927, and was subsequently amended as the Pesticide Products Act (PCPA) of 1939 (Flynn, 2002). In 1995, the Pest Management Regulatory Agency (PMRA) became a part of Health Canada which is responsible for the protection of human health and the environment including pesticide regulation of herbicides. Pesticides are regulated by the Pesticide Control Products Act (PCPA) of 2002 which was adopted in 2006 and managed by the Pest Management Regulatory Agency of Health Canada (Canadian Ministry of Justice, 2010). Tests for regulatory purposes are conducted in general accordance with U.S. and European guidelines.

\subsection{Herbicide registration and the risk assessment process}

Philosophically, the tiered assessment testing procedure follows the generalized framwork for ecological risk assessment that has been developed by a consortium of private, government, and academic institutions over the past 20 years (Fig. 2) (USEPA, 1998). The risk assessment process begins with a generalized problem formulation statement. For example, the problem formulation statement for the registration of an herbicide might by cast as "The production, application, and use of herbicide X may present an unacceptable risk to nontarget aquatic organisms". Based on this problem formulation statement, the risk assessment is conducted using an iterative assessment of the toxicity of an herbicide compared to its anticipated environmental exposure. Exposure and toxicity data are then integrated in the risk characterization step. If the risk characterization reveals some degree of concern then the problem can be re-evaluated with additional research and validation of exposure and toxicity in order to refine and minimize the risk. Excessive risk, defined as risk that cannot be managed or reduced, generally results in cancellation or removal of the chemical in the registration or re-registration process.

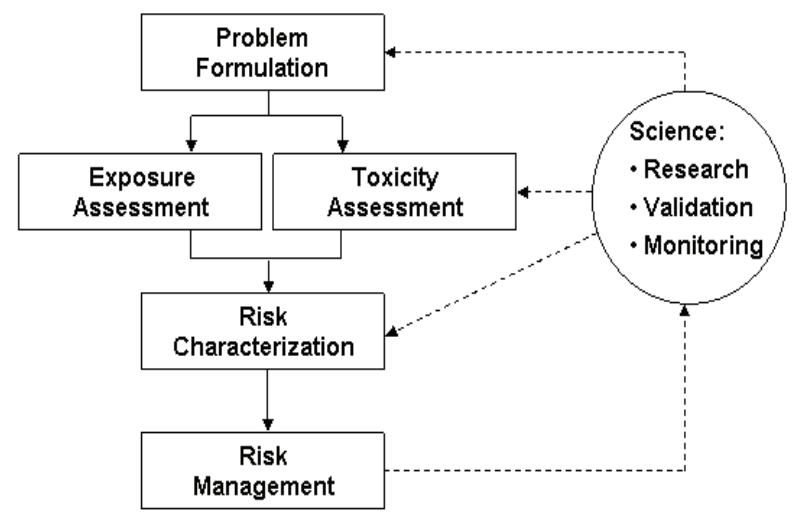

Fig. 2. Conceptual model for the framework for ecological risk assessment of herbicides and other chemicals (Source: USEPA 1998).

Registration of herbicides in the United States considers the potential for impacts on nontarget aquatic organisms and is conducted within a 4-tiered process (USEPA, 2010) (Table 3). 
Within each Tier, both toxicity and exposure are measured. The Tier 1 assessment consists of a comparison of the acute toxicity of an herbicide to a limited number of species potentially exposed to the maximum application rate of the chemical. The Tier 1 scenario is based on the assumption of a 10\% runoff of a single application of a chemical to a 10-ha field into a 1 ha pond with a depth of $2 \mathrm{~m}$. Fate predictions are made using standard exposure assessment models including the Pesticide Root Zone Model (PRZM), the Exposure Assessment Modeling System (EXAMS), and the GENeric Estimated Environmental Concentration (GENEEC2) models http://www.epa.gov/oppefed1/models/water/). These models predict a range of environmental exposures based on herbicide characteristics including water solubility, soil sorption coefficients, volatility, hydrolysis, photolysis, and biological degadation rates in soil and water. If the exposure/toxicity ratio exceeds 1 then tesing proceeds at the next highest tier. At each tier the data requirements expand to include more toxicity testing and additional chemical exposure assessment. Risk assessment at higher tiers varies depending on need, and can consist of mesocosm studies, field studies, field monitoring, and additional modeling including probablistic approaches.

\begin{tabular}{|l|l|l|}
\hline Tier & Toxicity Assessment & Exposure Assessment \\
\hline 1 & Acute testing $(8 \text { species })^{1}$ & Deterministic models (GENEEC2) \\
\hline 2 & Chronic testing $^{2}$ & Deterministic models (PRZM-3 and EXAMSII) \\
\hline 3 & Mesocosm field testing & \\
\hline 4 & Field monitoring & Probablistic modeling \\
\hline
\end{tabular}

1Short term (48h-96h) testing with eight species including 2 species of freshwater fish, 1 species of saltwater fish, 2 species of freshwater invertebrate, 1 species of saltwater invertebrate, and 2 species of aquatic plants.

2Includes fish early survival and growth; fish life cycle, and invertebrate life cycle.

${ }^{3}$ Experimental ecosystem testing under realistic environmental conditions.

${ }^{4}$ Reports of fish kills and onitoring studies at state/federal level.

Table 3. Example of the tiered assessment process used to assess risk of herbicides and other chemicals to non-target aquatic species during the pesticide registration process.

In probablistic modeling the probability of effects are compared to the probability of exposure to get a joint probability distribution of potential risk. Solomon et al. (1996) and Giddings et al. (2005) have conducted a series of probabalistic risk assessments with the herbicide atrazine. These probablistic risk assessments were possible due to the extensive datasabase available regarding the toxicity and environmental exposures to atrazine. A graphical example of the potential application of a probablistic assessment is presented in Figure 3. The data regarding probablity of exposure compared to plant and animal species sensitivity distributions indicates that the highest $20 \%$ of atrazine exposures would exceed the No Observable Effect Concentration (NOEC) values for approximately $10 \%$ of aquatic plant species (approximately $10 \mathrm{ug} / \mathrm{L}$ ) whereas animals would not be affected. Similar approaches have been used to demonstrate the low risk of diquat to invertebrate and fish populations (Campbell et al., 2000). The success of probabalistic modeling is currently being evaluated and will probably be routinely used in the registration process of new chemicals in the future based on structure/activity relationships and experience with widely studied chemicals such as atrazine. 


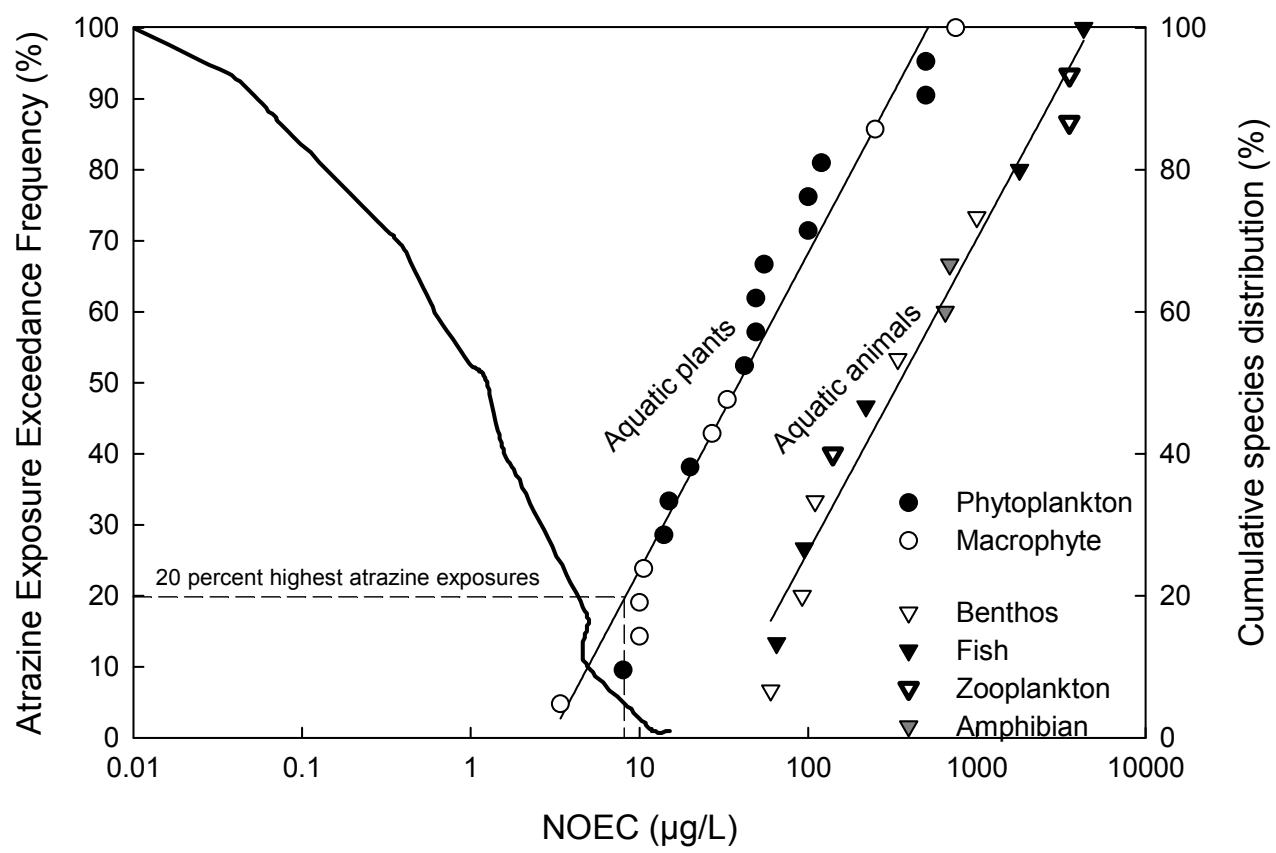

Fig. 3. Illustration of the concept of a an atrazine risk assessment based on joint probability distributions of measured environmental concentrations of atrazine in relation to the no observable effect concentrations (NOECs) determined under standardized laboratory conditions. The cumulative measured environmental exposure distribution is represented by the continuous line on the left. The other two lines with squares (aquatic plants) and triangles (benthos, zooplankton, amphibians, and fish) represent the linear cumulative species sensitivity distributions determined from chonic laboratory tests with atrazine. Plant data consists of published data from tests based on the endpoint of biomass production. Animal data consists of published data from tests on endpoints of survival, growth, or reproduction. The overlap between exposure and toxicity values represents the relative risk of exposure of plant and animal communities to atrazine. In this case, the highest 20 percent of atrazine exposures would exceed the NOEC level for aquatic plants approximately $10 \%$ of the time. No risk is anticipated for animals. Data extracted and redrawn from Giddings et al. (2005; copyright 2005 by the Society of Environmental Toxicology and Chemistry (SETAC), Pensacola, FL, USA.) Figure reprinted with permission.

\section{Herbicide exposures in aquatic ecosystems}

\subsection{Empirical measures of herbicide concentrations in water}

Extensive use of herbicides in the United States has led to widespread detection of parent compounds and metabolites in surface and groundwaters (Gilliom, 2007). There are extensive monitoring networks for herbicides to determine spatial and temporal trends in concentrations and loads in surface waters in the U.S. Plans for implementation of monitoring networks in Europe are planned over the next 5 years in association with the 
REACH legislation and the European Commission (Rabiet et al., 2010). The U.S. Geological Survey monitors herbicide concentrations at over 112 monitoring stations on a regular basis as part of its National Water Quality Assessment (NAWQA) and National Stream Quality Accounting Network (NASQAN) programs. Schnoebelen at al. (2003) monitored monthly herbicide concentrations at twelve fixed sites in the Eastern Iowa Basins NAWQA study unit from 1991-1998 and found that two herbicides, atrazine and metolachlor, were found in $100 \%$ of samples; acetachlor, cyanazine, alachlor, and bentazon were found in over $50 \%$ of samples (Fig. 4).

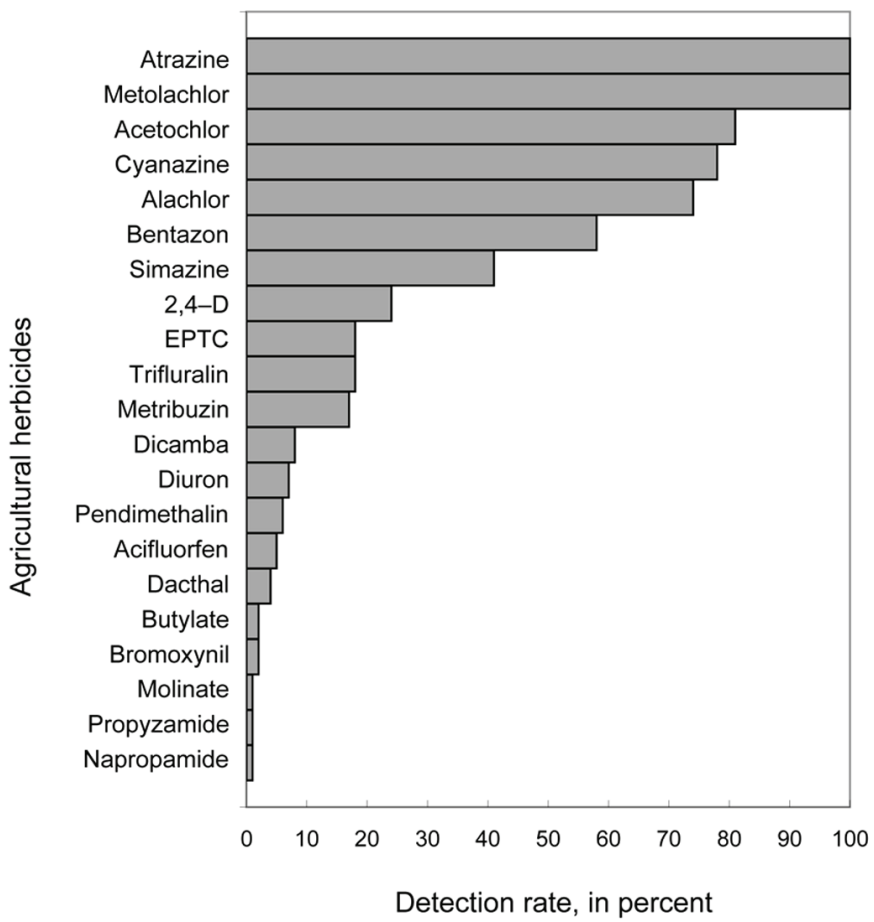

Data from Schnoebelen et al. (2003).

Fig. 4. Detection rates of herbicides monitored in Southern Iowa and Northern Missouri.

In one of the most intensive studies ever conducted, Richards and Baker (1993) monitored the concentrations of 6 herbicides daily at USGS gaging stations in 7 intensively-farmed Great Lakes tributaries from the months of April to August, 1983-1991 (Table 4). Concentrations were measured up to 3 times per day during peak exposure periods. Maximum concentrations of atrazine, alachlor, metolachlor, metribuzin, cyanazine, and linuron in the Lost Creek river basin were 68, 65, 64, 25, 23, and 13 ugL, respectively. However, these maximum concentrations were of short duration; maximum concentrations generally exceeded the $95 \%$ percentile concentrations by factors $>3$ and exceeded time weighted mean concentrations by over an order of magnitude. Lerch and Blanchard (2003) monitored concentrations of atrazine, cyanazine, acetochlor, alachlor, metolachlor, and metribuzin for 3 yrs (1997-1999) at 21 streams sites in Southern Iowa and Northern Missouri 
on an approximate weekly basis from April 15 to July 15. Atrazine was the most frequently detected herbicide and only rarely exceeded the annual $90^{\text {th }}$ percentile concentration (40 $\mathrm{ug} / \mathrm{L})$. These datasets illustrate the short duration of herbicide exposures in midwestern agricultural streams of the U.S. which are well below the majority of acute (EC50) and chronic (NOEC) levels for both algae and aquatic macrophytes and fall two orders of magnitude below levels causing effects on fish, invertebrates, and amphibians (USEPA, 2002; as summarized by Giddings et al., 2005).

\begin{tabular}{|c|c|c|c|c|c|c|c|}
\hline \multirow{2}{*}{$\begin{array}{l}\text { River Basin } \\
\left(\mathrm{km}^{2}\right) \\
\text { and } \\
\text { Cropland } \\
(\%)\end{array}$} & \multirow{2}{*}{ Parameter } & \multicolumn{6}{|c|}{ Herbicide and Concentration (ug/L) } \\
\hline & & Atrazine & Alachlor & Metolachlor & Metribuzin & Cyanazine & Linuron \\
\hline \multirow{4}{*}{\begin{tabular}{l|} 
Maumee \\
$(16,395$ \\
$\left.\mathrm{km}^{2}\right)$ \\
$(76 \%)$ \\
\end{tabular}} & $\mathrm{MAX}^{1}$ & 21.45 & 18.35 & 26.20 & 5.77 & 9.96 & 7.29 \\
\hline & 95 & 7.47 & 3.00 & 5.32 & 1.83 & 1.97 & 0.00 \\
\hline & 50 & 0.58 & 0.00 & 0.28 & 0.01 & 0.03 & 0.00 \\
\hline & $\mathrm{TWMC}^{2}$ & 1.61 & 0.54 & 1.16 & 0.29 & 0.38 & 0.05 \\
\hline \multirow{4}{*}{$\begin{array}{l}\text { Sandusky } \\
\left(3,240 \mathrm{~km}^{2}\right) \\
(80 \%)\end{array}$} & MAX & 24.61 & 36.13 & 36.76 & 9.26 & 19.87 & 0.02 \\
\hline & 95 & 8.84 & 3.76 & 8.59 & 1.68 & 1.73 & 0.29 \\
\hline & 50 & 0.53 & 0.00 & 0.35 & 0.00 & 0.00 & 0.00 \\
\hline & TWMC & 1.78 & 0.66 & 1.65 & 0.28 & 0.21 & 0.03 \\
\hline \multirow{4}{*}{$\begin{array}{l}\text { Honey Cr. } \\
\left(386 \mathrm{~km}^{2}\right) \\
(83 \%)\end{array}$} & MAX & 54.04 & 54.87 & 95.75 & 10.52 & 17.47 & 15.50 \\
\hline & 95 & 10.85 & 4.44 & 9.08 & 1.28 & 2.07 & 0.68 \\
\hline & 50 & 0.66 & \begin{tabular}{|l|}
0.11 \\
\end{tabular} & 0.35 & 0.00 & 0.03 & 0.00 \\
\hline & TWMC & 2.33 & 0.89 & 1.80 & 0.24 & 0.40 & 0.17 \\
\hline \multirow{4}{*}{$\begin{array}{l}\text { Rock Cr. } \\
\left(88 \mathrm{~km}^{2}\right) \\
(81 \%)\end{array}$} & MAX & 48.63 & 23.40 & 96.92 & 15.95 & 24.77 & 12.01 \\
\hline & 95 & 6.61 & 2.16 & 8.15 & 1.20 & 0.71 & 0.68 \\
\hline & 50 & 0.21 & 0.00 & 0.17 & 0.00 & 0.00 & 0.00 \\
\hline & TWMC & 1.34 & 0.39 & 1.62 & 0.23 & 0.18 & 0.15 \\
\hline \multirow{4}{*}{$\begin{array}{l}\text { Lost Cr. } \\
\left(11 \mathrm{~km}^{2}\right) \\
(83 \%)\end{array}$} & MAX & 68.40 & 64.94 & 63.64 & 25.15 & 22.62 & 13.44 \\
\hline & 95 & 5.67 & 1.07 & 3.08 & 0.80 & 1.64 & 0.00 \\
\hline & 50 & 0.27 & 0.00 & 0.00 & 0.00 & 0.00 & 0.00 \\
\hline & TWMC & 1.30 & 0.48 & 0.62 & 0.20 & 0.50 & 0.05 \\
\hline \multirow{4}{*}{\begin{tabular}{|l|} 
Cuyahoga \\
$\left(1,831 \mathrm{~km}^{2}\right)$ \\
$(4 \%)$
\end{tabular}} & MAX & 6.80 & 1.16 & 5.39 & 1.49 & 1.36 & 5.04 \\
\hline & 95 & 0.99 & \begin{tabular}{|l|}
0.24 \\
\end{tabular} & 0.63 & \begin{tabular}{|l|}
0.28 \\
\end{tabular} & 0.27 & 0.06 \\
\hline & 50 & 0.09 & 0.00 & 0.00 & 0.00 & 0.00 & 0.00 \\
\hline & TWMC & 0.31 & 0.04 & 0.15 & \begin{tabular}{|l|}
0.07 \\
\end{tabular} & 0.05 & 0.08 \\
\hline \multirow{4}{*}{\begin{tabular}{|l|} 
Raisin \\
$\left(2,699 \mathrm{~km}^{2}\right)$ \\
$(67 \%)$
\end{tabular}} & MAX & 12.86 & 7.52 & 5.91 & 2.46 & 3.75 & 1.92 \\
\hline & 95 & 3.91 & 2.02 & 1.50 & 0.37 & 1.11 & 0.18 \\
\hline & 50 & 0.30 & 0.00 & 0.00 & 0.00 & 0.00 & 0.00 \\
\hline & TWMC & 0.76 & 0.37 & 0.32 & 0.11 & 0.21 & 0.04 \\
\hline
\end{tabular}

${ }^{1}$ Maximum observed concentration (MAX).

2Time-weighted maximum concentration (TWMC).

Table 4. Concentrations of major herbicides in 7 Lake Erie Tributaries, Apr. 1983 - Dec. 1991. Data from Richards and Baker (1993). 


\subsection{Modeling of herbicide concentrations in water}

Exposure assessment in the pesticide registration process has primarily relied on use of deterministic models of worst-case assumptions of application and runoff. Peterson et al. (1994) modeled worst-case exposure estimates based on direct overspray of a 15-cm wetland at the maximum application rates of herbicides used in areas such as in prairie wetland areas of south-central Canada. This would rarely occur under prudent, recommended application practices. In the U.S. exposures are modeled in the herbicide registration and risk assessment process using Tier 1 (e.g., GENEEC2) and Tier 2 (e.g., PRZMII, EXAMS-3) models based on site-specific conditions including herbicide characteristics, application rates, soil types, slope, and rainfall patterns (USEPA, 2010). These Tier 1 and Tier 2 models were developed and validated using empirical data derived from edge-of-field studies conducted during the 1970s to measure the range of potential herbicide exposures in aquatic systems (e.g., Wauchope, 1978). Similar approaches are used in Europe (Huber et al., 2000).

Over the past decade more sophisticated models have been developed for higher-tier exposure assessments in the U.S. such as the Soil and Water Assessment Tool (SWAT; Gassman et al., 2007), and the Watershed Regression for Pesticides (WARP; Larson et al., 2004) and the Spatially Referenced Regression on Watershed Attributes (SPARROW; Schwarz et al., 2006) models. These higher-tier models use detailed data on soil characteristics, slope, rainfall patterns, pesticide use, and tillage patterns at various hydrologic unit scales across the nation. Recent efforts have been made to use these models to predict atrazine exposures in streams draining watersheds with highest atrazine use in order to implement site-specific monitoring programs that identify areas requiring exposure-reduction management plans (USEPA, 2006). Future development and application of these models will provide cost-effective yet sensitive methods to predict areas of highest herbicide exposures for use in both ecological and human health risk assessments.

\section{Herbicide effects in aquatic systems}

\subsection{Direct effects on aquatic plants}

The direct effects of an herbicide can be measured at either the structural or functional level. Structural endpoints include static measures of cell numbers, biomass, species composition, or community diversity. Functional endpoints are measured as changes in rates of biological processes such as carbon uptake, oxygen evolution, enzyme activity, nutrient cycling, population growth rates, or changes in system metabolism (e.g., gross production or community respiration). Both structural and functional endpoints can be measured at increasing hierarchical levels of biological organization ranging from the cell to the ecosystem to predict and assess the effects of herbicides on non-target aquatic organisms. Some functional measurements, such as the rate of enzymatic activity (e.g., peroxidase and glutathione transferase activity) are made at the plant cellular level and can be valuable in a research context because they are diagnostic of mode of action and occur rapidly at the cellular level (Field and Thurman, 1996; Ferrat et al., 2003). However, the utility and precision of these measurements is often dependent on plant species, herbicide mode of action, and other factors that make it difficult to use as an assessment endpoint for prediction of biological effects at higher levels of biological organization.

For regulatory and risk assessment purposes the direct effects of herbicides on aquatic plants are most often measured under standardized laboratory conditions using biomass production as the structural measurement endpoint. These studies are conducted under 
standardized conditions of lighting, temperature, and nutrient regimes using a relatively small cadre of species (e.g., algae and duckweed, etc.) (ASTM, 2009a, b). Although macrophytes are currently not routinely tested there are efforts underway in the U.S., Canada, and Europe to develop a standard toxicity test with a Myriophyllum sp. (Knauer et al., 2008; Kubitza and Dohmen., 2008). Single species laboratory tests are preferred for regulatory purposes due to their inherent precision, replicability, repeatability and reproducibility at relatively low monetary costs. Although no species is universally more sensitive to herbicides than another, these standard tests are commonly used to determine the toxicity of a chemical, the relative sensitivity of a number of species to a chemical, or the relative toxicity of a group of chemicals (Fairchild et al., 1997; 1998).

Herbicide effects are usually expressed as the EC50 based on regression analysis of standing crop biomass (i.e., the effective concentration of herbicide that reduces the amount of plant biomass at a fixed interval such as 4 days, 7 days, or two weeks). For example, Hughes et al. (1988) evaluated the effects of atrazine on single species aquatic plant biomass production in the laboratory over a 5-d period. Responses among species were similar with an average 120-h EC50 of $170 \mu \mathrm{g} / \mathrm{L}$ (95\% C.I. 130-230 $\mu \mathrm{g} / \mathrm{L})$. Hughes et al. (1988) further compared the 120 -d EC50 to several other possible endpoints including the phytostatic concentration (i.e., the concentration totally stopping plant population growth) and the phytocidcal concentration (i.e., the concentration that results in total plant populaton mortality/sterilization). The EC50 values were highly conservative compared to $120-\mathrm{h}$ phytostatic concentrations (average 1,720 $\mu \mathrm{g} / \mathrm{L}$, range 1,450 - 4,970 $\mu \mathrm{g} / \mathrm{L}$ ) and the 120-h phytocidal concentrations $(>3,200 \mu \mathrm{g} / \mathrm{L}$, the highest concentration tested). Moreover, plants recovered at all concentrations once removed to clean water. This study illustrates that the most commonly used endpoint in aquatic plant ecotoxicology may be useful in comparing the relative sensitivity of various species under standardized conditions. However, for the purposes of a risk assessment, plant data must be interpreted totally differently compared to standard measurement endpoints measured in acute toxicity tests with animals such as zooplankton and fish where individual mortality is measured (e.g., 96-h LC50). While herbicides may temporarily suppress growth of non-target algae and macrophytes, populations quickly recover once exposure is reduced. Therefore, aquatic plants have intrinsic adaptive factors that allow them to tolerate herbicides in the environment where exposures are typically low and ephemeral (Table 4).

One of the greatest criticisms of single species tests is that they are ecologically unrealistic. Singles species tests do not reflect the complexity of natural systems that contain multispecies communities of algae, bacteria, and other communities in association with natural sediment and nutrient conditions which provide the biological capacity for structural and functional redundancy, resilience, and recovery. To overcome the limitations of single species tests, studies are often conducted in simulated experimental ecosystesms such as microcosms, mesocosms, and outdoor experimental ponds.

Larsen et al. (1986) examined the effects of atrazine in single species laboratory tests and experimental microcosms in order to compare the utility of single species tests for predicting community-level responses under more realistic conditions. Laboratory EC50 values were determined for 8 species of algae exposed to atrazine for $24 \mathrm{hr}$ using ${ }^{14} \mathrm{C}$ uptake as a measurement endpoint. Single species EC50 values ranged from 37 - $308 \mathrm{ug} / \mathrm{L}$ with an average response at approximately $100 \mathrm{ug} / \mathrm{L}$ atrazine. These same species were studied in microcosms containing the same eight algal species along with two protozoans, an amphipod, an ostracod sp., a Daphnia sp., and bacterial/fungal communities in a static 
system containing a silica sand substrate. Microcosms were exposed for 60 days to atrazine at nominal concentrations of $0,60,100,200$, and $500 \mathrm{ug} / \mathrm{L}$ atrazine. Effects of atrazine were measured and compared at three intervals: early (days 10 to 20), late (days 53 to 60) and then averaged across the entire study. Short-term decreases in functional measures of ${ }^{14} \mathrm{C}$ uptake occurred in the microcosms immediately after dosing in all treatments, but recovery occurred in the 60 and $100 \mathrm{ug} / \mathrm{L}$ treatments within 10 days following treatment. ${ }^{14} \mathrm{C}$ uptake was reduced at 200 and $500 \mathrm{ug} / \mathrm{L}$ throughout the study with little recovery. Functional measures of algal community effects in the microcosms ranged from $103-154 \mathrm{ug} / \mathrm{L}$ for ${ }^{14} \mathrm{C}$ uptake, 126 - $165 \mathrm{ug} / \mathrm{L}$ for oxygen production, and from 106 - $164 \mathrm{ug} / \mathrm{L}$ for oxygen consumption, which approximated the average functional responses measured in single species studies. In contrast, algal biomass measured as chlorophyll $a$ actually increased at 60,100 , and $200 \mathrm{ug} / \mathrm{L}$ in a hormetic fashion indicating that functional measures were more sensitive indicators of stress but not accurate in terms of estimating production of algal biomass. Single species laboratory tests based on biomass production are now known to be conservative for prediction of effects in outdoor mesocosms and most probably field effects.

DeNoyelles et al. $(1982 ; 1986)$ conducted a series of experimental pond studies with atrazine over a 3-yr period in order to compare the relative structural and functional responses of natural plant communities to atrazine. Three studies were conducted during this time, with atrazine exposures at $0,20,100,200$, and $500 \mathrm{ug} / \mathrm{L}$. Mesocosms exposed to environmentally relevant concentrations of $20 \mathrm{ug} / \mathrm{L}$ atrazine exhibited short term decreases in algal functional measures of ${ }^{14} \mathrm{C}$ uptake and dissolved oxygen production but quickly recovered to control values for the remainder of the studies, and no structural changes in phytoplankton were ever observed in the $20 \mathrm{ug} / \mathrm{L}$ concentration. EC50 values for ${ }^{14} \mathrm{C}$ uptake and algal biomass were 100 and $82 \mathrm{ug} / \mathrm{L}$, indicating that community structural and functional measures were similar in sensitivity. Atrazine altered species compositions of algae at $100 \mathrm{ug} / \mathrm{L}$, but sensitive species were replaced by more tolerant species with no changes in overall algal biomass or productivity. Both structural and functional changes in algal communities were observed at 200 and $500 \mathrm{ug} / \mathrm{L}$ atrazine; however, these high concentrations are now known to be environmentally irrelevant. Collectively, the pond studies indicated that predictions made using the most sensitive algal species under standardized laboratory conditions overestimated the predicted response of algal communities in ponds due to species replacement which provided functional redundancy at concentrations of $100 \mathrm{ug} / \mathrm{L}$ atrazine.

Fairchild et al. (1994) examined the effects of atrazine applied in combination with an insecticide (esfenvalerate) to determine if atrazine would alter the effects of the insecticide on consumer populations. The dominant macrophyte in the mesocsoms, Najas sp., has been shown to be sensitive to the herbicide atrazine under laboartory conditions at $24 \mathrm{ug} / \mathrm{L}$ (14-d EC50; Fairchild et al. 1998). Atrazine, applied to ponds at $50 \mathrm{ug} / \mathrm{L}$, shifted the macrophyte community to a community dominated by Chara sp. Total macrophyte biomass and system metabolism did not change due to atrazine. Rapid sorption of the strongly hydrophobic esfenvalerate $\left(\mathrm{T}_{1 / 2} 48 \mathrm{~h}\right)$ by aquatic plants and sediments mitigated the precicted effects of the insecticide on zooplankton dynamics and bluegill survival/growth. Therefore, alteration of one measure of ecosystem structure (macrophyte species composition) was mitigated by another measure of community structure (total biomass) and function (system metabolism) to remove any adverse effects adverse effects of an insecticide on consumer (bluegill) populations. 
Fairchild et al. (2002) exposed the same experimental pond system to the triazinone herbicide metribuzin at $0,9,19,38$, and $75 \mathrm{ug} / \mathrm{L}$. Najas sp., the dominant macrophyte species, had been shown to be sensitive to metribuzin in the laboratory at $19 \mathrm{ug} / \mathrm{L}$ (14-d EC50) which was similar to 4 other species of macrophytes (14-d EC50, range 17- $36 \mathrm{ug} / \mathrm{L}$ metribuzin) (Fairchild et al., 1998). Although metribuzin is more toxic to macrophytes (14-d EC50s ranging from 21-132 ug/L) than atrazine under laboratory conditions the relatively short half-life of metribuzin $\left(\mathrm{T}_{1 / 2}=5\right)$ days observed in the ponds resulted in no effects on water quality, periphyton biomass, macrophyte species composition, macrophyte biomass, or fish survival/growth.

Numerous other microcosm and mesocosm studies have been conducted with other herbicides including 2,4-D, hexazinone, linuron, simazine, and terbutryn. Brock et al. (2000) reviewed the results of a total of 124 microcosm and mesocosm studies of the effects of herbicides in model aquatic systems. Rigorous evaluation criteria included the following requirements: 1) the study must have had published single species toxicity data for the chemical; 2) the study must have included multiple species at different trophic levels; 3) the study was ideally conducted outdoors to allow the potential for biological recolonization; 4) the study used an appropriate experimental design (e.g. replication of treatments) ; and 5) the study must have resulted in a statistically significant lowest observable effect concentration (LOEC) of an accepted structural or functional endpoint. Very few of the studies reviewed by Brock et al. (2000) met the strict criteria for acceptance due to statistical problems, inadequate descriptions of methodologies, or concerns due to methodologies such as isolation techniques or the availability for recolonization of plants and other organisms. Significant ecological effects in studies that fully met acceptance criteria were only observed in cases where exposure concentrations exceeded those considered environmentaly relevant. Therefore, there is no compelling evidence from these studies that herbicides are likely to impact aquatic plants in the environment.

Brock et al. (2000) summarized the strengths, weaknesses, and utility of various approaches for evaluating the statistical and ecological relevance of various test systems that have historically been used to assess the risk of herbicides to non-target aquatic plants (Fig. 5). Laboratory single species tests are relatively simple to conduct and exhibit high precision and reproducibility. Single species laboratory studies are therefore useful for comparing the relative sensitivity of different species to an herbicide or the relative toxicity of several herbicides. Studies in microcosms and mesocosms have been a useful approach for validating laboratory and model predictions of the fate and effects of herbicides in aquatic environments due to their increasing realism and complexity which approximates anticipated responses under actual field conditions. However, it could be argued that additional mesocosm tests with herbicides that meet the Brock (2000) criteria are needed.

From an objective perspective the current tiered testing procedures in use by the USEPA are useful, cost-effective approach for the risk assessment of herbicides and other chemicals. Testing at higher tiers currently allows for flexibility in using either mesocosm/field testing or probablistic modeling of effects and exposure data. Current experience increasingly indicates that probablistic risk assessment of herbicide effects using single species laboratory toxicicity data and environmental exposure data similar to that described by Solomon et al. (1996) and Giddings et al. (2005) (visually illustrated in figure 3) can be used to effectively evaluate the potential for non-target effects of herbicides in aquatic systems for regulatory and risk assessment purposes. Although mesocosm tests can be used in the U.S. for registration purposes, past experience has indicated that these studies are relatively 
expensive due to the scarcity of available testing facilities and monetary costs associated with meeting quality assurance guidelines required by the USEPA. For these reasons, probabilistic risk assessments using single species laboratory data are increasingly being emphasized in regulatory programs for herbicide registration and re-registration in both the U.S. and Europe (Reach, 2007; USEPA, 2010).

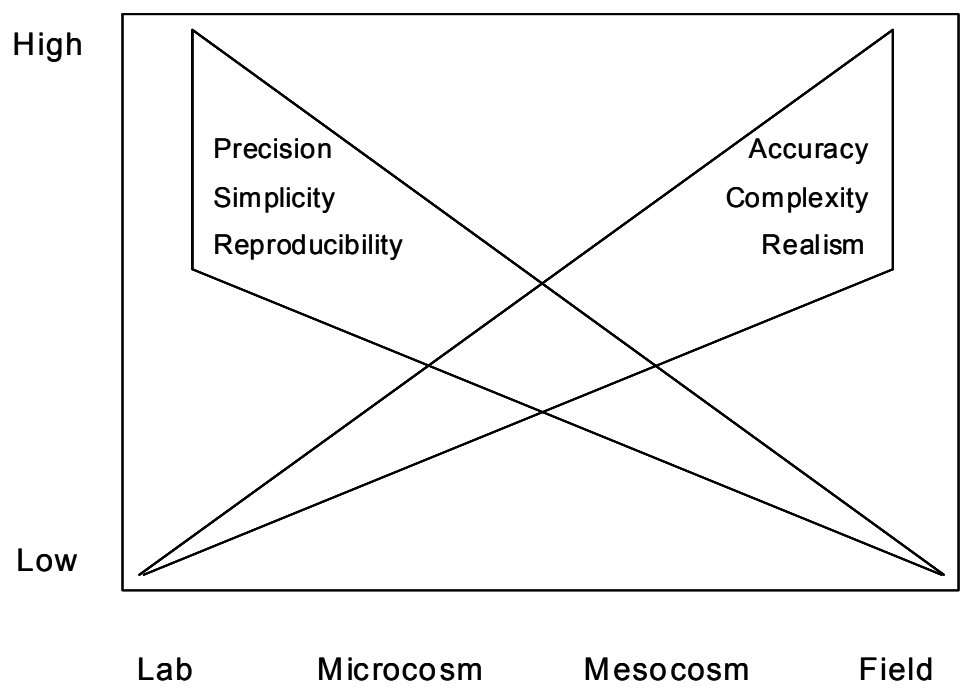

Fig. 5. Illustration of the continuum of strengths and weakness of various test systems used for the risk assessment of herbicides. Figure adapted from Brock et al. (2000).

\subsection{Direct effects on invertebrates, fish, and amphibians}

Direct effects of herbicides on animals are usually measured at the individual level of biological organization. As with plants, most herbicide risk assessments using invertebrates, fish, and amphibians are conducted in the laboratory using standardized species and methods. Animal tests are somewhat easier to conduct than plant tests because environmental factors such as nutrient regimes, lighting, and invasion of unwanted test organisms are less critical. Endpoints can include both structural (e.g., survival) and functional (e.g., growth and reproduction) measurements.

Few if any environmentally relevant concentrations have been shown to have direct effects on zooplankton, fish, or amphibians in the laboratory. This is well-illustrated in Figure 3 for the herbicide atrazine and data provided within two extensive ecological risk assessments of the chemical (Solomon et al., 1996; Giddings et al., 2005). Similar wide margins of safety have recently been shown for survival and growth of rainbow trout exposed to the herbicides picloram, 2,4-D, and clopyralid (Fairchild et al., 2009a, b, c). This is not surprising given the basic modes of action of herbicides and the phylogenetic differences between plants and animals. Field monitoring programs conducted by the USGS National Water Qaulity Assessment (NAWQA) program and the USEPA Environmental Monitoring and Assessment Program (EMAP) have found degraded aquatic communities in intensivelyfarmed watersheds. However, herbicides have never been shown to be associated with or 
causal of these effects; excessive levels of nutrients, sediments, and hydrologic alterations interact to produce these ecological impairments.

One practical way to illustrate the lack of direct effects of herbicides on invertebrates, fish, and amphibians is to examine the use of herbicides for control of aquatic nuisance plants. There are approximately 10 herbicides registered for aquatic use by the U.S. Environmental Protection Agency (Table 5). These registered herbicides represent several different chemical classes and associated modes of action. Aquatic herbicides are usually used to control native and non-native macrophytes such as Eurasian millfoil (Myriophyllum spicatum) and other species that interfere with desired aquatic uses including swimming, boating, and water delivery/supply. Given this intent, recommended application rates for aquatic herbicides are much higher than single species EC50s in order to reach a phytostatic or phytocidal concentration (Table 5).

\begin{tabular}{|l|l|l|l|l|}
\hline & Chemical & $\begin{array}{l}\text { Recommended } \\
\text { Application Rate } \\
(\mathrm{mg} / \mathrm{L})^{1}\end{array}$ & $\begin{array}{l}\text { Aqueous } \\
\text { Half-life } \\
(\mathrm{d})^{1}\end{array}$ & $\begin{array}{l}\text { Bluegill } \\
\text { EC50 } \\
(\mathrm{mg} / \mathrm{L})^{1}\end{array}$ \\
\hline Copper & Metal & 1 & $2-8$ & $1-12$ \\
\hline Endothall & Dicarboxylic acid & $2-4$ & $1-7$ & 240 \\
\hline Diquat & Bipyridilium & $0.1-0.5$ & $1-4$ & 67 \\
\hline Fluridone & Pyridinone & $0.010-0.020$ & $20-80$ & 14 \\
\hline Glyphosate & Amino-acid derivative & $0.5-5.0$ & $5-10$ & $>1000$ \\
\hline Imazamox & Imadizolinone & $0.005-0.025$ & $25-50$ & $>120$ \\
\hline Imazapyr acid & Imadizolinone & 1.0 & $3-5$ & $>100$ \\
\hline Penoxsulam & Sulfanilamide & $0.005-0.025$ & $25-50$ & $>103$ \\
\hline Triclopyr acid & Pyridine & 1.0 & $0.5-3$ & 148 \\
\hline 2,4-D acid & Phenoxy acid & 1.0 & $2-6$ & 2600 \\
\hline Atrazine 4 & Triazine & $1.72^{4}$ & $3-120^{4}$ & 28.3 \\
\hline
\end{tabular}

${ }^{1}$ Application rate and aqueous half-life data derived from University of Florida accessed on 7/28/2010 at http://plants/ifas/ufl.edu/guide/sup3herb.html.

${ }^{2}$ Glyphosate is a surface contact herbicide and is not phyto-toxic when applied directly to water. ${ }^{3}$ Note that atrazine is not registered for aquatic use; value derived from Hughes et al. (1988).

${ }^{4}$ Values reported in Giddings et al. (2005) as summarized from USEPA (2002).

Table 5. Chemical names, application rates, aqueous half-life, and toxicity of herbicides to fish (bluegill) registered for aquatic plant control by the USEPA.

It is reasonable to assume that phytocidal concentrations of herbicides such as those registered and used to remove aquatic plants can induce both direct and indirect effects at the population, community, and ecosystem levels of biological organization. For example, when macrophytes are deliberately removed from a system there are major structural changes in habitat when macrophyte-dominated systems are converted to phytoplanktondominated systems. In fact, this is often the stated goal in use of herbicides for control of nuisance aquatic plants to restore native plants. Research has demonstrated that macrophyte community structure is a major factor controlling predation rates of higher level consumers such as largemouth bass on bluegill (Savino and Stein, 1982; Crowder and Cooper, 1982; Wiley et al., 1984). Loss of aquatic macrophytes following deliberate vegetation removal by herbicides can also have profound effects on ecosystem function including alteration of 
nutrient cycling, decreased water transparency due to wave action and bioturbation, and depletion of dissolved oxygen concentrations. Many fish kills attributed to registered aquatic-use herbicides are due to the indirect effects of oxygen depletion. Therefore, consideration must be given to the timing of application of herbicides in relation to temperature, dissolved oxygen, and standing crop of macrophyte biomass. Altered nutrient cycling and increases in turbidity following aquatic plant removal efforts are major functional indicators of the role of aquatic plants in lakes and reservoirs. However, these are ecosystem changes that are often accepted by the public in order to meet management and restoration goals in aquatic systems. These herbicide concentrations used for aquatic plant control, however, far exceed any environmentally relevant concentrations resulting from agricultural use.

\section{Indirect effects}

Indirect effects of herbicides are defined as observed effects on consumer populations such as invertebrates and fish that are not caused by direct toxicity but rather effects that have occurred due to adverse effects on primary producers such as algae and macrophytes. Previous studies have implied that the herbicide atrazine can have indirect effects on consumer populations in aquatic ecosystems at concentrations as low as $0.1 \mathrm{ug} / \mathrm{L}$ (Lampert et al. 1989). Dewey et al. (1986) reported a decrease in macroinvertebrate emergence in pond microcosms treated at $20 \mathrm{ug} / \mathrm{L}$ atrazine; in addition, Kettle et al. (1987) reported total reproductive failure in ponds treated at $20 \mathrm{ug} / \mathrm{L}$. However, recent critical reviews of these studies by Giddings et al (2005) have revealed that the indirect effects observed by Lampert et al. (1989) on plankton communities were actually due to the effects of a solvent used to deliver atrazine which drove the system into a heterotrophic state; the indirect effects reported by Dewey et al. (1986) and Kettle et al. (1987) were not caused by atrazine, but rather the differential growth and survival of aquatic macrophytes due to the effects of grass carp (aquatic herbivores) and channel catfish (bluegill predators) that were not disclosed in the original manuscripts. Therefore, environmentally relevant concentrations of herbicides such as atrazine are not known to cause indirect effects on aquatic systems.

Recently, researchers have applied bioenergetic ecosystem-based models in order to predict the direct effects of herbicides on primary producers and ultimately indirect effects on consumer populations such as fish in an attempt to add ecological realism to the risk assessment process. Bartell et al. (2000) used the Comprehensive Aquatic Systems Model (CASM) which is an ecological model based on demographics and bioenergetic equations used to model the direct and indirect effects of the aquatic herbicide diquat on phytoplankton and zooplankton populations in Florida lakes. Bartell et al. (2000) showed potential for direct effects on phytoplankton but little probability for indirect effects of diquat on zooplankton consumers. Currently, the CASM model is being used to determine locations where concentrations and exposure durations of atrazine in streams may pose risks to consumer populations via indirect, dietary effects. This model is being used with intensive monitoring at selected sites in the re-registration of atrazine in order to identify areas of atrazine exposure that may require adaptive management actions to reduce risk (USEPA, 2006). However, ecological process models such as CASM are mathematically complex and require an extreme level of expertise to use and apply in a regulatory context. Therefore the utility of using ecological process models for herbicide regulatory purposes is contentious. 


\section{Emerging areas of research on herbicide effects on endocrine and immune function in aquatic vertebrates}

Over the past decade there has been a tremendous amount of research regarding potential effects of atrazine on the endocrine and immune function in vertebrates including amphibians, fishes, and reptiles. Atrazine has been widely studied because of its frequency of detection in surface and groundwaters (Solomon et al., 1996; Schnoebelen et al., 2003) due to its widespread application (34-36 million kilograms per year in the U.S.; Kiely et al., 2004), high water solubility (33 mg/L; Wauchope et al., 1992), and long aqueous half-life (mean $159 \pm 71$ d; range 41-237 d; Giddings et al. 2005). Hayes et al. (2002; 2003) reported that male larval African clawed frogs (Xenopus laevis) exposed to atrazine at $<1.0 \mathrm{ug} / \mathrm{L}$ exhibited hermaphrodism and altered laryngeal development; in addition, male X. laevis suffered a 10 -fold decrease in testosterone levels when exposed to $25 \mathrm{ug} / \mathrm{L}$ atrazine. The authors hypothesized that atrazine induces aromatase that promotes the conversion of testosterone to estradiol. These publications prompted numerous studies of the effects of atrazine on a vast array of physiological responses of vertebrates to atrazine. Solomon et al. (2008) conducted a critical review of over 75 atrazine studies with amphibians to evaluate reported effects on sexual differentiation, sexual development, male laryngeal development, and thyroid function; an additional 20 studies of the effects of atrazine on endocrine and behavioural functions in fishes were also examined. Solomon et al. (2008) concluded that "based on a weight of evidence of all the data, the central theory that environmentally relevant concentrations of atrazine affects reproduction, and/or reproductive development in fish, amphibians, and reptiles is not supported by the majority of observations. The same conclusions also hold for the supporting theories such as induction of aromatase, the enzyme that converts testosterone to estradiol".

Many studies have shown feminization effects in amphibians, fishes, and reptiles when exposed to the synthetic hormone $17 \mathrm{~B}$ estradiol which is a standard positive control chemical for studies of endocrine function and reproductive effects; however, the metabolism, mode of action, and effects of estradiol are well-studied and known. The same cannot be said for atrazine. Solomon et al. (2008) found that the majority of studies reporting atrazine effects on endocrine and immune function contained substantial weaknesses in the areas of experimental design, methodologies, interpretation, and inferences; no studies have directly established cause and effect relationships in the laboratory or field based on established principles of epidemiology. More recently, Rohr and McCoy (2010) conducted a meta-analysis of the effects of atrazine on freshwater amphibians and fish and indicated that atrazine reduced size at metamorphosis in 15 of 17 studies in 14 species; reduced immune function in 33 of 43 studies; altered gonadal morphology in 7 of 10 studies; and altered spermatogenesis in 2 of 2 studies. However, the exact mechanisms of individual-level effects and ultimate significance in populations of amphibians, fish, and reptiles remain uncertain. The existing concerns of the effects of atrazine and other possible chemicals on endocrine function in aquatic and semi-aquatic vertebrates remain controversial. These concerns led the USEPA to implement an amphibian metamorphosis (frog) test and a fish short-term reproduction test for assessment of potential endocrine-disrupting effects of herbicides and other chemicals on non-target aquatic organisms (USEPA, 2010). Research in this active area of ecotoxicology continues. 


\section{Research needs and conclusions}

Research and monitoring has indicated that the widespread use of herbicides in modern agriculture has led to widespread exposures of aquatic organisms in aquatic systems. The observed high sensitivity of a few species of algae and macrophytes to herbicides has been used to infer that adverse effects on aquatic ecosystems may occur. Therefore, systematic assessment procedures that evaluate the fate and effects of herbicides on non-target aquatic organisms have been developed. Risk assessments of herbicides for registration and regulatory puroposes consist of single species laboratory toxicity tests and exposure models within a tiered testing system. Atrazine is currently one of the greatest herbicides of regulatory concern because it is a generalized inhibitor of photosynthesis, is commonly detected in aquatic systems, and has a long environmental half-life compared to other herbicides. Atrazine is occassionally observed in the environment at concentrations of 50 $\mathrm{ug} / \mathrm{L}$ or higher but exposures at this level only occur over short time durations. The effects of herbicides on non-target aquatic plant communities in natural environments are likely attenuated or mitigated due to the adaptive abilities of aquatic plants through acclimation and recovery following exposures; species substitution; and functional redundancy of aquatic plant communities. Cases of direct effects of herbicides on plant communities only occur during the intentional use of registered aquatic herbicides that are deliberately applied at phytostatic or phytocidal concentrations. Studies of direct and indirect effects of herbicides on invertebrates, amphibians, and fish exposed to environmentally relevant concentrations using accepted measurement endpoints of survival, growth, and reproduction have not shown adverse effects in laboratory, mesocosms, or field situations.

Research regarding the effects of atrazine on endocrine and immune function continues, but remains highly controversial. Mechanistic and comphrehensive studies of atrazine need to be conducted under laboratory and field conditions in order to establish cause and effect relationships. Once these studies are conducted, additional studies will be needed to determine the ultimate ecological significance of these effects in the field at the population level of amphibians and fishes.

\section{Acknowledgments}

Any use of trade, product, or firm names is for descriptive purposes only and does not imply endorsement by the U.S. Government. This manuscript was produced using U.S. Geological Survey funds only; no private or outside funds were solicited or used.

\section{References}

American Society for Testing and Materials (ASTM). (2009a). Standard guide for conducting static 96h toxicity tests with microalgae: Practice E1218-90. In: Annual Book of ASTM Standards: Water and Envrionmental Technology. S.J. Baily and N.C. Baldini, (Ed), pp. 293-306, ASTM Committee E-47 on Biological Effects and Envrionmental Fate, American Society for Testing and Materials, West Conshohoken, PA. 1618 pp.

American Society for Testing and Materials (ASTM). (2009b). Standard guide for conducting toxicity tests with Lemna gibba G3. Practice E1415-91. In: Annual Book of ASTM Standards: Water and Environmental Technology. S.J. Baily and N.C. Baldini (Ed), pp. 
623-632, ASTM Committee E-47 on Biological Effects and Envrionmental Fate, American Society for Testing and Materials, West Conshohoken, PA.1618 pp.

Bartell. S.M., K.R. Campbell, C.M. Lovelock, S.K Nair, and J.L Shaw. (2000). Characterizing ecological risks from pesticides using a diquat bromide case study II: Ecological process models. Toxicol. Chem. 19:1441-1453.

Brock, T.C.M., R.P. van Wijigaarden, and G.J. van Geest. (2000). Ecological risks of pesticides in freshwater ecosystems. Part 1: Herbicides. Aterra-Rapport 088. Alterra, Green World Research, Wageningen, the Netherlands. $127 \mathrm{pp}$.

Campbell, K.R., S.M. Bartell, and J.L. Shaw. (2000). Characterizing aquatic ecological risks from pesticides using a diquat dibromide case study II: Approaches using quotients and distributions. Toxicol. Chem. 19: 760-774.

Canadian Ministry of Justice. (2010). Pesticide control products: consolidation. Minister of Justice, SOR/2006-124. Accessed at http://laws-lois.justice.gc.ca, Aug. 18, 2010.

Cole, D., Pallett, K., and M. Rodgers. (2000). Discovering new modes of action for herbicides and the impact of genomics. Pestiicde Outlook, December, pp. 223-229.

Crowder, L.B. and W.E. Cooper. (1982). Habitat structural complexity and the interaction between bluegills and their prey. Ecology 63:1802-1813.

deNoyelles, F., Jr., W. D. Kettle, and D. E. Sinn. (1982). The responses of plankton communities to atrazine, the most heavily used pesticide in the United States. Ecology 63:1285-1293.

deNoyelles, F., Jr., and W.D. Kettle. (1985). Experimental ponds for evaluating bioassay predictions. In: Validation and Predictability of Laboratory Methods for Assessing the Fate and Effects of Contaminants in Aquatic Systems, T.P. Boyle, (Ed), pp. 91-103, ASTM STP 865, American Society for Testing and Materials., Philadelphia, PA. 242 pp.

Dewey, S.L.(1986). Effects of the herbicide atrazine on aquatic insect community structure and emergence. Ecology 67:148-162.

Fairchild, J.F., T.W. La Point, and T. Schwartz. (1994). Effects of an herbicide and insecticide mixture in experimental aquatic mesocosms. Arch. Tox. Chem. 27:527-533.

Fairchild, J.F., D.S. Ruessler, P.S. Haverland, and A.R. Carlson. (1997). Comparative sensitivity of Selenastrum capricornutum and Lemna minor to sixteen herbicides. Arch. Environ. Contam. Toxicol. 32:353-357.

Fairchild, J.F, D.S. Ruessler, and A.R. Carlson. (1998). Comparative sensitivity of five species of macrophytes and six species of algae to atrazine, metribuzin, alachlor, and metolachlor. Toxicol. Chem. 17:1830-1834.

Fairchild, J.F. and L.S. Sappington. (2002). Fate and effects of the triazinone herbicide metribuzin in outdoor aquatic mesocosms. Environ. Contam. Toxicol. 43:198-202.

Fairchild, J.F., K.P Feltz, A. Allert, L.S. Sappington, K.J. Nelson, and J. Valle. (2009a). An ecological risk assessment of the acute and chronic effects of picloram to rainbow trout (Onchorhyncus mykiss) and the threatened bull tourt (Salvelinus confluentus). Arch. Environ. Contam. Toxicol. 56:761-769.

Fairchild, J.F., K.P. Feltz, A. Allert, L.S. Sappington, K.J. Nelson, and J. Valle. (2009b). An ecological risk assessment of the exposure and effects of 2,4-D acid to rainbow trout (Oncorhynhcus mykiss). Arch. Contam. Toxicol. 56: 754-760. 
Fairchild, J.F., A.L. Allert, K.P. Feltz, K.J. Nelson, and J. Valle. (2009c). An ecological risk assessment of the acute and chronic effects of the herbicide clopyralid to rainbow trout (Oncorhynhcus mykiss). Arch. Environ. Contam. Toxicol. 57:725-731.

Ferrat, L. C. Pergnet-Martini, and M. Romeo. (2003). Assessment of the use of biomarkers in aquatic plants for the evaluation of environmental quality: application to seagrasses. Aquat. Tox. 65: 187-202.

Field, J.A. and E.M. Thruman. (1996). Gultathione conjugation and contaminant transformation. Environ. Sci. Tech. 30: 1413-1418.

Flynn, D.J. (2002). Herbicide legislatation and regulation. In: Weed Management Handbook, R.E. Naylor, Ed., Pp. 114-133, British Crop Protection Council, Blackwell Publishing, Oxford, UK. 423 pp.

Gassman, P.W., M.R. Reyes, C.H. Green, and J.G. Arnold. (2007). The Soil and Water Assessment Tool: historic development, applicatioins, and future research directions. Amer. Soc. Agricul. Biol. Eng. 50(4): 1211-1250

Gianessi, L.P., and N.P. Reigner. (2007). The value of herbicides in U.S. crop production. Weed Technol. 21:559-566.

Giddings, J.M., T.D. Anderson, L.W. Hall, Jr., A.J. Hosmer, R.J. Kendall, R.P. Richards, K.R. Solomon, and W.M. Williams. (2005). Atrazine in North American surface waters: probabalistic aquatic ecological risk asssessment. SETAC Press, Pensacola FL. 392 pp.

Gilliom, R.J. (2007). Pesticides in streams and groundwater. Environ. Sci. Tech. 41:3408-3414.

Hayes, T.B, A. Collins, M. Lee, N. Mendoza, N. Noirega, A.A. Stuart, and A. Vonk. (2002). Hermaphtoditic, demasculinized frogs after exposure to the herbicide atrazine at low ecologically relevant doses. Proc. Nat. Acad. Sci. 99:5477-5480.

Hayes, T.B., K. Haston, M. Tsui, A. Hoang, C. Haeffele, and A. Vonk. (2003). Atrazineinduced hermaphrodism at $0.1 \mathrm{ppb}$ in American leopard frogs (Rana pipiens): laboratory and field evidence. Environ. Health Perspect. 11:568-575.

Kubitza, J. and Dohmen, G.P. (2008). Development of a test method for the aquatic macrophyte Myriophyllum aquaticum. SETAC Europe 18th Annual Meeting, Warsaw, 2008.

Huber, A., M. Bach, and H.G. Frede. (2000). Pollution of surface waters with pesticides in Germany: modeling non-point source inputs. Agricul. Ecosys. 80:191-204.

Hughes, JS., MM Alexander, and K Balu. (1988). An evaluation of appropriate expressions of toxicity in aquatic plant bioassays as demonstrated by the effects of atrazine on algae and duckweed. In: Adams, W, GA Chapman, and WG Landis, ed. Volume 10, Aquatic Toxicology and Hazard Assessment, American Society for Testing and Materials, p. 531-547.

Kettle, W.D., F. deNoyelles, J.D. Heacock, and A. Kadoum. (1987). Diet and reproductive success of bluegill recovered from experimental ponds treated with atrazine. Bull. Environ. Contam. Toxicol. 38:47-52.

Knauer, K., Mohr, S., and U. Feiler. (2008). Comparing growth development of Myriophyllum spp. in laboratory and field experiments for ecotoxicological testing. Sci. Pollut. Res. 15:322-331.

Kiely, T., D. Donaldson, and A. Grube. (2009) Pesticide industry sales and usage: 2000 and 2001 market estimates. U.S. Environmental Protection Agency Office of Prevention, EPA-733-R-04-001, Washington, DC. 33 pp. 
Kubitza, J., and G.P. Dohmen. (2008). Development of a test method for the aquatic macrophyte Myriophyllum aquaticum. SETAC Europe 18th Annual Meeting, Warsaw, 2008.

Lampert, W., W. Fleckner, E. Pott, U. Schober, and K.U. Storkel. (1989). Herbicide effects on planktonic systems of different complexity. Hydrobiologia 188/189:415-424.

Larsen, D.P., F. deNoyelles, F. Stay, and T. Shiroyama. (1986). Comparisons of singlespecies, microcosm, and experimental pond responses to atrazine exposure. Toxicol. Chem. 5:179-190.

Larson, S.J., C.G. Crawford, and R.J. Gilliom. (2004). Development and application of watershed regressions for pesticides (WARP) for estimating atrazine concentrations in streams. U.S. Geological Survey Water Resources Investigations Report 03-4047. Environ. Toxicol. Chem. 68 pp.

Lerch, R.N., and P.B. Blanchard. (2003). Watershed vulnerability to herbicide transport in northern Missouri and southern Iowa streams. Environ. Sci. Technol. 37:5518-5527.

Menne, H., and H Kocher. (2007). HRAC classification of herbicides and resistance development. In: Modern Crop Protection Compounds, W. Kramer and U. Schirmer, Ed., pp. 5-26, Wiley-VCH Publishing, Weingeim, Germany.

Moss, R.S. (2002). Herbicide-resistant weeds. In: Weed Management Handbook, R.E. Naylor, Ed., Pp. 225-252, British Crop Protection Council, Blackwell Publishing, Oxford, UK. 423 pp.

Peterson, H.G., C. Boutin, P.A. Martin, K.E. Freemark, N.R. Ruecker, and M.J. Moody (1994). Aquatic phyto-toxicity of 23 pesticides applied at expected environmental concentrations. Aquat. Toxicol. 28:275-292.

Rabiet, M., C. Margoum, V. Gouy, N. Carluer, and M. Coquery. (2010). Assessing pesticide concentrations and fluxes in the stream of a small vineyard catchment - effect of sampling frequency. Environ. Pollut. 158: 737-748.

REACH. 2007. Regulation on Registration, Evaluation, Authorization and Restriction of Chemicals. http://ec.europa.eu/environment/chemicals/reach/reach_intro.htm, accessed July 15, 2010.

Read, J.P.H., and A.H. Cobb. (2002) Herbicide modes of action and metabolism. In: Weed Management Handbook, R.E. Naylor, Ed., Pp. 134-170, British Crop Protection Council, Blackwell Publishing, Oxford, UK. 423 pp.

Richards, R.P., and D.B. Baker. (1993). Pesticide concentration patterns in agriculutural drainage networks in the Lake Erie Basin. Toxicol. Chem. 12:13-26.

Ritter, A.M, J.L. Shaw, W.M. Williams, and K.Z. Travis. (2000). Characterizing aquatic ecological risks from pesticides using a diquat dibromide case study I: Probablistic expousre estimates. Environ. Toxicol. Chem. 749-759.

Rohr, J.R., and K. McCoy. (2010). A qualitative metal analysis reveals consistent effects of atrazine on freshwater fish and amphibians. Environ. Health Perspect. 118:20-32.

Saundry, P. (2006). Federal Insecticide, Fungicide, and Rodenticide Act, Unites States. In: Encyclopedia of Earth, C.J. Cleveland, (Ed.), pp. 1-6, Congressional Research Service, Envrionmental Information Coalition, National Council for Science and the Envrironment, Washington, DC. Accessed Aug. 18, 2010, http://www.eoearth.org/article/Federal_Insecticide_Fungicide_and_Rodenticide_ Act)_United_States. 
Savino, J.F. and R.A. Stein. (1982). Predator-prey interaction between largemouth bass and bluegill as influenced byin simulated, submerged vegetation. Trans. Amer. Fish. Soc. 111: 255-266.

Schnoebelen, D.G., S.J. Kalkhoff, K.D. Becher, and E.M. Thurman. (2003). Water quality assesssment of the eastern Iowa basins: selected pesticides and pesticide degradates in streams, 1996-1998. U.S. Geological Survey Investigations Report 03-4075. 62 pp.

Schwarz, G.E., A.B. Hoos, R.B. Alexander, and R.A. Smith. (2006). The SPARROW surface water quality model: theory, application, and user documentation. U.S. Geological Survey Techniques and Methods Book 6, Section B, Chapter 3. 29 pp.

Solomon, K.R., D.B. Baker, R.P. Richards, K.R. Dixon, S.J. Klaine, T.W. La Point, R.J. Kendall, C.P. Weisskopf, J.M. Giddings, J.P. Giesy, L.W. Hall Jr., and W.M. Williams. (1996). Ecological risk assesssment of atrazine in North American surface waters. Environ. Toxicol. Chem. 15:31-76.

Solomon, K.R., J.A. Carr, L.H. DuPreez, J.P. Giesy, R.J. Kendall, E.E. Smith, and G.J. VanderKraak. (2008). Effects of atrazine on fish, amphibians, and aquatic reptiles: a critical review. Crit. Rev. Toxicol. 38:721-772.

USEPA. (1998). Guidelines for Ecological Risk Assessment. U.S. Environmental Protection Agency, Risk Assessment Forum, EPA/630/R095/002F, Washington, DD. 188 pp.

USEPA. (2002). Ecotoxicity pesticide database.

http://www.epa.gov/oppefed1/general/databasesdescription.htm\#ecotoxicity

USEPA. (2006). Decision documents for atrazine. Accessed Aug. 8, 2010 at http://www.epa.gov/oppsrrd1/REDs/atrazine_combined_docs.pdf. 323 pp.

USEPA. (2010). U.S. EPA Office of Chemical Safety and Pollution Prevention (OCSPP). http://www.epa.gov/ocspp/pubs/frs/home/guidelin.htm, accessed July 15, 2010.

Wauchope, R.D. (1978). The pesticide content of surface water draining from agricultural fields- a review. Rev. Environ. Qual. 7:459-472.

Wauchope, R.D., T.M. Buttler, A.G. Hornsby, P.W.M. Augustijn-Beckers, and J.P. Burt. (1992). The SCS/ARS/CES pesticide properties database for environmental decision-making. Rev. Contam. Toxicol. 123:1-164.

Weed Management Handbook (2002). Naylor, E.L., editor. Blackwell Science, $9^{\text {th }}$ edition.

Wiley, M.J., R.W. Gorden, S.W. Waite, and T. Powless. (1984). The relationship between aquatic macrophytes and sport fish populations in Illinois ponds. N. Amer. J. Fish Manage. 4:111-119. 


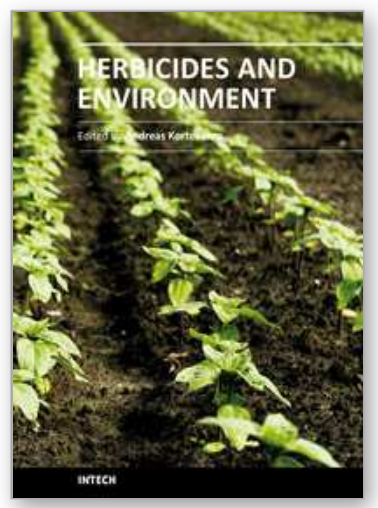

\author{
Herbicides and Environment \\ Edited by Dr Andreas Kortekamp
}

ISBN 978-953-307-476-4

Hard cover, 746 pages

Publisher InTech

Published online 08, January, 2011

Published in print edition January, 2011

Herbicides are much more than just weed killers. They may exhibit beneficial or adverse effects on other organisms. Given their toxicological, environmental but also agricultural relevance, herbicides are an interesting field of activity not only for scientists working in the field of agriculture. It seems that the investigation of herbicide-induced effects on weeds, crop plants, ecosystems, microorganisms, and higher organism requires a multidisciplinary approach. Some important aspects regarding the multisided impacts of herbicides on the living world are highlighted in this book. I am sure that the readers will find a lot of helpful information, even if they are only slightly interested in the topic.

\title{
How to reference
}

In order to correctly reference this scholarly work, feel free to copy and paste the following:

James Fairchild (2011). Structural and Functional Effects of Herbicides on Non-Target Organisms in Aquatic Ecosystems with an Emphasis on Atrazine, Herbicides and Environment, Dr Andreas Kortekamp (Ed.), ISBN: 978-953-307-476-4, InTech, Available from: http://www.intechopen.com/books/herbicides-andenvironment/structural-and-functional-effects-of-herbicides-on-non-target-organisms-in-aquatic-ecosystemswith-a

\section{INTECH}

open science | open minds

\section{InTech Europe}

University Campus STeP Ri Slavka Krautzeka 83/A 51000 Rijeka, Croatia Phone: +385 (51) 770447 Fax: +385 (51) 686166 www.intechopen.com

\section{InTech China}

Unit 405, Office Block, Hotel Equatorial Shanghai No.65, Yan An Road (West), Shanghai, 200040, China 中国上海市延安西路65号上海国际贵都大饭店办公楼405单元 Phone: +86-21-62489820

Fax: +86-21-62489821 
(C) 2011 The Author(s). Licensee IntechOpen. This chapter is distributed under the terms of the Creative Commons Attribution-NonCommercialShareAlike-3.0 License, which permits use, distribution and reproduction for non-commercial purposes, provided the original is properly cited and derivative works building on this content are distributed under the same license. 